\title{
DATING THE TAVAN TOLGOI SITE, MONGOLIA: BURIALS OF THE NOBILITY FROM GENGHIS KHAN'S ERA
}

\author{
M Youn ${ }^{1} \bullet \mathrm{J} \mathrm{C} \mathrm{Kim}^{2} \bullet \mathrm{H} \mathrm{K} \mathrm{Kim}{ }^{3} \bullet \mathrm{D} \mathrm{Tumen}^{4} \cdot \mathrm{D} \mathrm{Navaan}^{4} \bullet \mathrm{M} \mathrm{Erdene}^{4}$
}

\begin{abstract}
The Tavan Tolgoi (Five Holy Hills) site, located in Ongon sum, Sukhbaatar aimag, in southeastern Mongolia, consists of about 20 burials. During the preliminary 2004 excavations conducted by the Department of Anthropology and Archaeology, National University of Mongolia, 7 graves were unearthed. In grave 1 (2004), the skeleton of a woman $40 \mathrm{yr}$ old, wearing golden rings with the inscription of a Siberian falcon, was found together with other ornamental artifacts. In grave 2 (2004), a man with a gold-gilded saddle and a horse were buried. Adornments strongly indicate that these burials date to the Great Mongol Empire period and may relate to the Golden Horde lineage of Genghis Khan. Initial accelerator mass spectrometry (AMS) radiocarbon dating of wood from a coffin at burial 2004-6 (Table 1) gave an age of $860 \pm 60 \mathrm{BP}$, and the age of a human bone sample from burial 2004-1 was determined as $890 \pm 40$ BP. Subsequent excavations yielded 13 samples for ${ }^{14} \mathrm{C}$ dating, and 7 of them have been dated thus far. The calibrated dates were in the range of AD 1130-1250, which is in agreement with Genghis Khan's life span. Artifacts strongly suggest that these burials belong to nobility or members of the royal family. Given that such burials are hard to find, the Tavan Tolgoi site is expected to yield important archaeological and historical information. In this paper, the historical importance of the artifacts recovered is discussed in light of ${ }^{14} \mathrm{C}$ dating and the results of additional scientific analyses.
\end{abstract}

\section{INTRODUCTION}

Nomadic tribes of Mongolia in the Middle Ages, particularly during the 12th and 13th centuries, played a significant role not only in the history of the region but also of most of Europe and Asia. The Great Mongol Empire, established by Genghis Khan in AD 1206 and expanded by his sons and grandsons, integrated different cultural, linguistic, and economic groups. The empire covered the territory from the Yellow Sea to eastern Europe and from southern Siberia to Southeast Asia. The enigma of a relatively small group of nomadic people who managed to conquer such an enormous territory, and who founded the largest contiguous land empire ever known within a time span of a generation, has attracted the attention of scholars.

Historical evidence relating to the Mongol Empire is extensive. Besides records written in Chinese and Persian and several travel reports, a number of indigenous historical texts, such as the Secret History of the Mongols (Damdinsuren 1947), as well as medieval inscriptions discovered in the territory of Mongolia, provide important textual information about the Great Empire. In addition, systematic archaeological studies of the Mongol period provide an independent record of material evidence, which, when combined with the indigenous and external historical records, makes up an impressive body of information for understanding Mongol culture, traditions, and political organization during the Great Empire.

Archaeological investigations in Mongolia and adjacent territories led to the discovery of different monuments belonging to this period, such as settlement ruins, stone-men, rock and wooden inscriptions, and burial grounds. Burials from the Mongol Empire are found all over Mongolia and southern Siberia. Around 300 graves have been excavated in Mongolia and the neighboring Buryat Republic of Russia, and the majority of them appear to be graves of commoners. The mortuary sites

\footnotetext{
'National Center for Inter-University Research Facilities, Seoul National University, Seoul, 151-742, Korea.

Corresponding author. Email: myoun63@snu.ac.kr.

${ }^{2}$ School of Physics, Seoul National University, Seoul, 151-747, Korea.

${ }^{3}$ Department of Pathology, Medical College, Korea University, Seoul, 13-701, Korea.

${ }^{4}$ Department of Anthropology and Archaeology, National University of Mongolia, Ulaanbaatar-46, Mongolia.
} 
of medieval commoners are easily recognized by their distinctive surface features. Mongol burials typically have slightly mounded oval- or round-shaped stone features made up of medium-sized stones, are oriented north-south or northeast-southwest, and are almost always located in southern or southeastern hillsides. The spatial pattern of these burials discloses a wide dispersal across the landscape. There are no large cemeteries; instead, burials are usually grouped into small clusters with 2 or 3 (maximum of 20) burials together (Turbat et al. 2003). Below the surface stone features, these graves consist of pits ( 0.5 to $2 \mathrm{~m}$ deep) with interred supine individuals in a stretched position, deposited either in wooden coffins or directly in the pit. Associated mortuary materials include iron scissors, knives, arrow points, birch bark containers and arrow quivers, earrings, and bones of sheep and goats. Horse-related equipment such as bridles and stirrups are also frequently found.

The paucity of studies concerning elite burials from the period of the Mongol Empire can be explained by the long-standing tradition of keeping ancestors' burial grounds secret. Historical sources mention that soon after the funeral, the burial site of a high-ranking person may have been trampled down by thousands of horses in order to make it unidentifiable. Furthermore, burial site names were kept undisclosed, and were instead called Ihesiin gazar ("Dignity's site") (Amar 1934).

Based on a few known cases of nobility burials belonging to the Mongol Empire period, it has been established that the surface structure and spatial features of these graves are considerably different from those of commoners' graves (Anonymous 2000; Bayar 2000). Mortuary treatment of the nobility differs significantly from the smaller burials of commoners. This can probably be explained by differences in social status.

This paper concerns the accelerator mass spectrometry (AMS) radiocarbon dating of artifacts from the Tavan Tolgoi site. Based on the results and other scientific analyses, we discuss 2 topics that help us to understand the history and tradition of medieval Mongols: mortuary treatment of the nobility in the Mongol Empire, and the relationship of the Tavan Tolgoi site to the Golden Horde lineage of Genghis Khan.

\section{SITE DESCRIPTION}

The location of the Tavan Tolgoi site $\left(45^{\circ} 06^{\prime} 00.5^{\prime \prime} \mathrm{N}, 112^{\circ} 43^{\prime} 07.1^{\prime \prime} \mathrm{E}[1104 \mathrm{~m}\right.$ asl]) is given in Figure 1. The Tavan Tolgoi is a group of rocks on hill slopes amidst a plain, located $47 \mathrm{~km}$ southeast of the Ongon district center in Sukhbaatar province, southeastern Mongolia. The region was inhabited by Mongol nomadic tribes for centuries, and it is located roughly between Karakorum, the 13th century capital of the Mongol Empire, and Dadu, the Yuan Dynasty capital. The site is unique because 2 stone-men depicting medieval Mongol aristocrats (male and female) are situated near the burials.

Burial grounds are scattered on the southern slope of the central hill of Tavan Tolgoi, and are marked by a post at the top. All of the graves have a similar surface structure: a ring-shaped stone construction 6 to $8 \mathrm{~m}$ in diameter (Figure 2). Graves with this type of structural feature are typically dated to the Xiongnu period, 2nd century BC-1 st century AD (Batsaikhan 2002).

\section{Grave 1 (2004)}

Besides its ring-shaped stone construction, this grave also has a unique ceremonial feature on its north side. The headless skeleton of a horse with a gilded saddle was found here, at a depth of $3.5 \mathrm{~m}$ below the surface. To the right lay a female skeleton, oriented to the west. Her skeleton had been preserved in anatomical order, and she was determined to be in approximately her late 40s (Tumen 


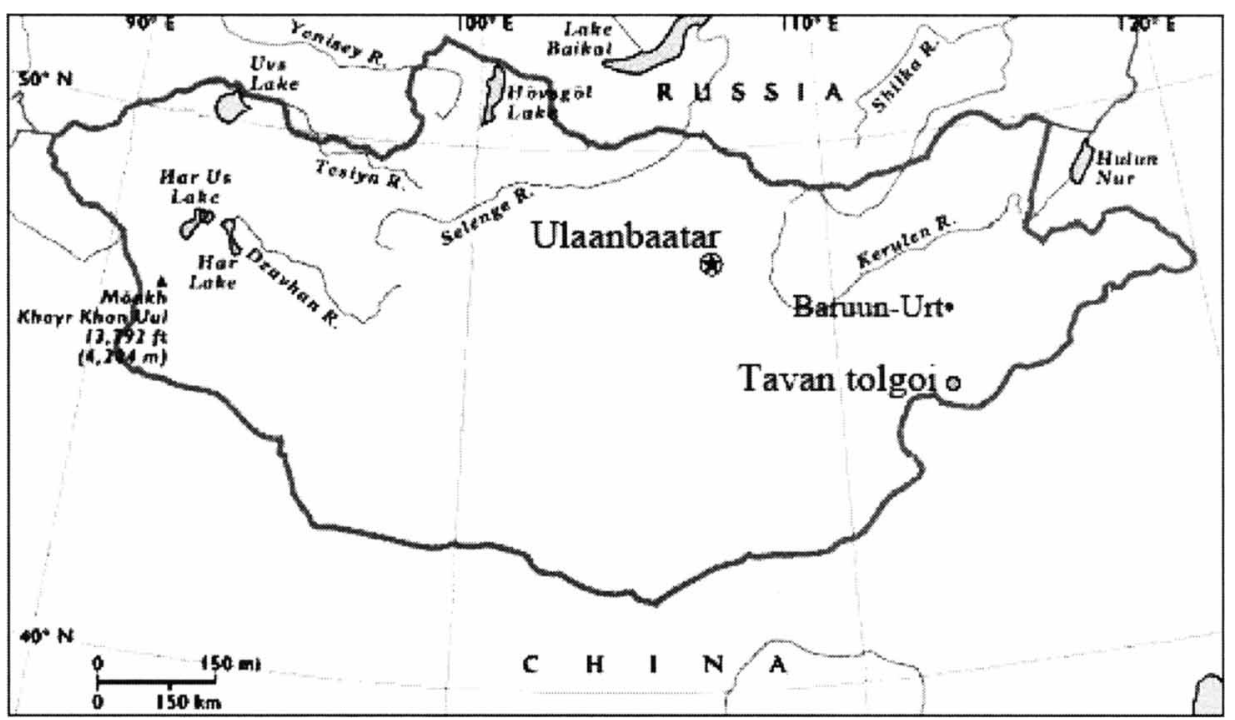

Figure 1 Geographical location of the Tavan Tolgoi site in Mongolia

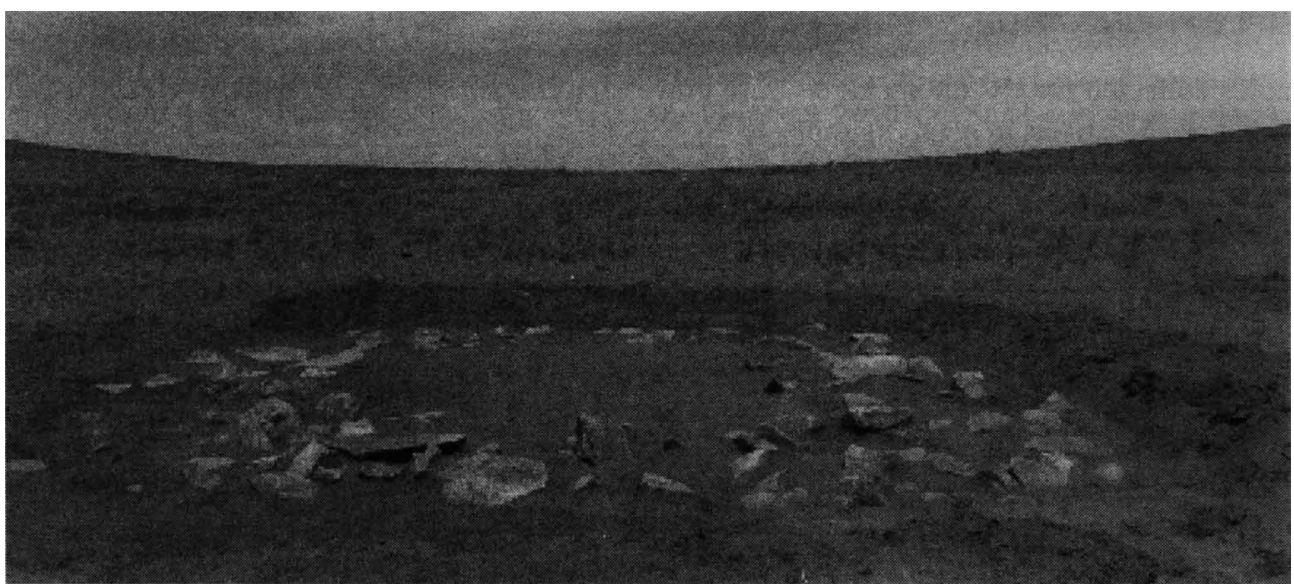

Figure 2 Surface structure of one of the Tavan Tolgoi site graves

2004). The woman was found with a golden ring on one of the fingers of her left hand; the inner surface of the ring was sealed with the image of a falcon.

\section{Grave 2 (2004)}

Grave 2 is located near grave 1 (2004) and contains the skeleton of a male holding silk in his hands. A large pearl wrapped in silk was found resting upon a golden base. The pearl had been set on a flower-shaped base called a jins in Mongolian, and it was used as a marker of social status. The remains of golden thread were also found among the artifacts, suggesting that the jins was part of a man's hat. Anthropological data show that the man was likely in his 30s (Tumen 2004). 


\section{Grave TT-2005 B-5}

A horse skeleton, harnessed and wearing a gilded saddle, was found at a depth of $1.3 \mathrm{~m}$. The front and back plate bow and the base of the saddle were all hammered and contain images of a dragon. To the right of the horse lay human remains in a wooden coffin, separated from the horse by the remains of a large stone. A human skeleton was found in anatomical order, despite being poorly preserved. Excavations also revealed various golden and silver goods associated with the burial of an interred supine female. The female is estimated to have been in her late 30s. She wore a golden ring on one of the fingers of her left hand and a golden crown on her head. A pair of golden earrings was found near her skull. We assume this grave belonged to a person of high social status based on the golden artifacts.

\section{Grave TT-2005 B-7}

Horse vertebrae and hooves were found 1.5 to $1.7 \mathrm{~m}$ below the surface of this grave. At a depth of $2.10 \mathrm{~m}$, a well-preserved wooden coffin oriented north-south was unearthed. The human remains it contained were completely disarticulated, and the skull with its mandible was found outside the coffin. Based on the grave's structure and its artifacts, which included a wooden coffin, horse equipment, and a single golden earring, we assume that this grave dates to the Mongol Empire period, and that it too belonged to an individual of high social status.

\section{SAMPLE PREPARATION}

Samples collected for ${ }^{14} \mathrm{C}$ dating came from graves 1 (2004), 2 (2004), TT-2005 B-5, and TT-2005 B-7, and are described in detail in Table 1.

Table 1 Description of samples for ${ }^{14} \mathrm{C}$ dating.

\begin{tabular}{|c|c|c|}
\hline Sample ID & Lab code \& $\mathrm{nr}$ & Sample description \\
\hline CW 2004-6 & SNU05-016 & Piece of coffin wood from grave 2 (2004); larch; Larix sp. \\
\hline TB 2004-1 & SNU05-040 & Human tarsal bone from grave 1 (2004) \\
\hline T1 2004-1 & SNU05-536 & $\begin{array}{l}\text { Piece of a finely woven textile (outer garment) from grave } 1 \\
\text { (2004) }\end{array}$ \\
\hline RB 2004-1 & SNU05-537 & Two pieces of human rib bones from grave 1 (2004) \\
\hline T3 2004-1 & SNU05-538 & $\begin{array}{l}\text { Pieces of textile adhered to the inner surface of the left hip bone } \\
\text { from grave } 1(2004)\end{array}$ \\
\hline CW 2005-7 & SNU05-539 & Coffin wood fragment from grave TT-2005 B-7 \\
\hline WT 2005-5 & SNU05-540 & Wood fragments adhered to textiles from grave TT-2005 B-5 \\
\hline
\end{tabular}

For the textile materials, a standard acid-base-acid (ABA) procedure (Park 2003:40) was performed. Bone samples were demineralized by repeatedly soaking overnight in $0.25 \mathrm{M} \mathrm{HCl}$ at room temperature. The bone collagen was converted into gelatin in $0.01 \mathrm{M} \mathrm{HCl}$ at $58{ }^{\circ} \mathrm{C}$. Using an ultrafiltration step, the gelatin was isolated and dried for combustion (Cheoun et al. 2001). For wood samples, $\alpha$-cellulose was extracted by applying $\mathrm{NaClO}_{2}$ after base treatment, with a final acid treatment in $0.5 \mathrm{M} \mathrm{HCl}$ at $80-85^{\circ} \mathrm{C}$ (Park 2003:45). Pretreatment was followed by combustion to obtain $\mathrm{CO}_{2}$ gas. Subsequent reduction converted the $\mathrm{CO}_{2}$ into graphite using hydrogen gas and an Fe catalyst (Kim et al. 2000; Lee et al. 2000). After reduction, the ion source cathode target was made from graphite. 


\section{RADIOCARBON DATING}

The graphite targets were placed in the Cs-sputtering ion source of the tandem-type electrostatic accelerator (Model 4130 Tandetron, High Voltage Engineering Europa, BV) at Seoul National University (Kim et al. 2001) for ${ }^{14} \mathrm{C}$ dating. As a standard, we use NIST oxalic acid (OxII). One standard sample was measured for every 5 to 7 samples to be dated. We also measured IAEA C3, C4, and C5 samples (Rozanski et al. 1992) to monitor the AMS dating reliability. In order to assess the sample contamination, the carbon/nitrogen $(\mathrm{C} / \mathrm{N})$ ratio was examined for a subset of samples for which enough amount remained to perform an analysis using an elemental analyzer (Model EA1110, CE Instruments). The results are shown in Table 2 together with measured ${ }^{14} \mathrm{C}$ ages and $\delta^{13} \mathrm{C}$ values. Calibration was performed using OxCal v 3.10 (Bronk Ramsey 1995, 2001) and the IntCal04 calibration curve (Reimer et al. 2004).

Table 2 Results of ${ }^{14} \mathrm{C}$ dating and subsequent calibration of the Tavan Tolgoi site.

\begin{tabular}{lccll}
\hline Lab code and $\mathrm{nr}$ & $\begin{array}{l}{ }^{14} \mathrm{C} \text { date } \\
(\mathrm{BP})\end{array}$ & $\begin{array}{l}\text { Calibrated date } \\
(\mathrm{cal} \mathrm{AD} \pm 2 \sigma)\end{array}$ & $\begin{array}{l}\delta^{13} \mathrm{C} \\
(\%)\end{array}$ & $\begin{array}{l}\mathrm{C} / \mathrm{N} \text { ratio } \\
(\%)\end{array}$ \\
\hline SNU05-016 & $860 \pm 60$ & $1030-1270$ & -29.7 & 0.38 \\
SNU05-040 & $890 \pm 40$ & $1030-1220$ & -17.2 & - \\
SNU05-536 & $770 \pm 200$ & $750-1650$ & -25.7 & 0.50 \\
SNU05-537 & $670 \pm 90$ & $1180-1440$ & -19.5 & - \\
SNU05-538 & $790 \pm 40$ & $1170-1290$ & -25.8 & 0.50 \\
SNU05-539 & $1680 \pm 60$ & $230-540$ & -27.1 & - \\
SNU05-540 & $830 \pm 40$ & $1150-1280$ & -24.3 & 0.50 \\
\hline
\end{tabular}

Because the amount of $\mathrm{CO}_{2}$ after combustion was very small for sample SNU05-536, the intensity of carbon beams from the ion source was only $10 \%$ of the nominal value. The resulting statistical error was therefore larger compared with other dated samples, and the result showed quite a wide error range, although the centroid of the age range coincides with that of other dates. We postpone any discussions concerning this date until a new measurement is performed using a sufficient amount of sample.

The $\mathrm{C} / \mathrm{N}$ ratios are in the range of $0.38-0.50$, which implies that the contamination level may be regarded as negligible. For grave 1 (2004), where samples represent bones and textiles, it was possible to assume a coincidence of the artifacts. Based on this assumption, we applied a statistical analysis using OxCal v 3.10 (Bronk Ramsey 1995, 2001). The result shown in Figure 3 manifests a set of boundaries ranging from AD 1160-1280. The error represents the systematic error and the statistical error combined. For other burials, we rely on a single ${ }^{14} \mathrm{C}$ date for each site.

Dating for the sample of the coffin wood from grave TT-2005 B-5 (SNU05-539) shows its calibrated age to be between the 3rd and 6th centuries AD. This date is excluded from the age determination of the Tavan Tolgoi site.

\section{DISCUSSION AND CONCLUSION}

Comparing the archaeological findings, the state of the graves, and the rituals at the Tavan Tolgoi site, archaeologists proposed that the burials date mainly to the 12 th-13th centuries AD, the period of the Mongol Empire. The artifacts from 3 burials-grave 1 (2004), grave 2 (2004), and grave TT$2005 \mathrm{~B}-5$ - were dated to the 11 th-13th centuries $\mathrm{AD} .{ }^{14} \mathrm{C}$ dates therefore confirm the archaeological estimation, and the $\mathrm{C} / \mathrm{N}$ ratio indicates that contamination was kept negligible. The calibrated dates are in the range of AD 1030-1440 (Table 2). 


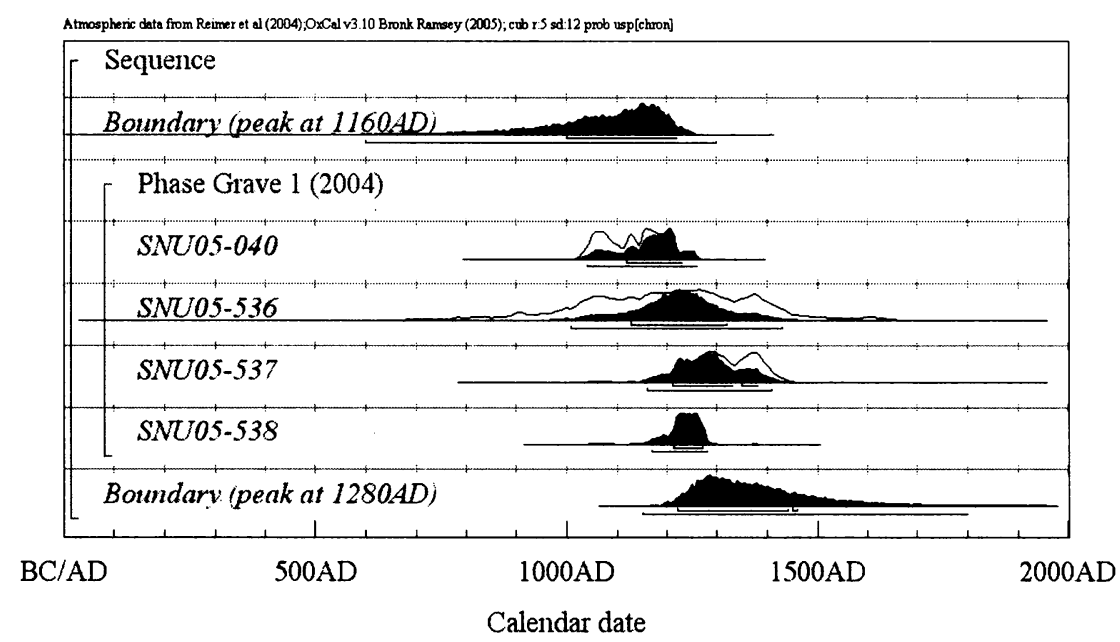

Figure 3 Bayesian analysis (OxCal v 3.10; Bronk Ramsey 1995, 2001) of ${ }^{14} \mathrm{C}$ dates from grave 1 (2004) of the Tavan Tolgoi burial ground. The calculated probability boundaries suggest a date in the 12 th-13th centuries AD.

The golden ring with the falcon seal inside it, from grave 1 (2004), shows a close relationship with burial sites dating to the Golden Horde lineage of Genghis Khan. The falcon is mentioned in the histories dating from Genghis Khan's Golden Horde, including historical manuscripts and legends of the 12th-13th centuries. For example, in the 63rd part of the Secret History of Mongols (Damdinsuren 1947), Temüüjin (Genghis Khan) was described as a falcon, a totem of the Hiyad Borjigin tribe. The findings-including the grave of the man with a jins marker, the burial of a woman wearing a ring with an inscribed falcon seal, a horse with a gilded saddle, and other jewelry - are the first of their kind in Mongolia, and they are of the utmost importance to the history of the Mongol Empire.

Parallel with the ${ }^{14} \mathrm{C}$ dating, a histological investigation of human bones and an ecological study of wooden material from the coffins were performed (Kim 2005). The results revealed that the wood from the coffin of grave TT-2005 B-7 is cinnamon (Cinnamonum sp.), while the sample taken from the coffin of grave 2 (2004) is larch (Larix sp.). Considering the climatic conditions necessary for the growth of these trees, the cinnamon wood is noteworthy because these trees currently grow in hot and humid regions of Southeast Asia, at least several thousand kilometers away from the site. One of the characteristics of cinnamon trees is that they grow neither fast nor big; it usually takes $60 \mathrm{yr}$ for a cinnamon tree to grow up to a diameter of $\sim 60 \mathrm{~cm}$. Based on such characteristics, we suggest that the discrepancy in the age of sample SNU05-539 may be due to the age of the tree used for the coffin, which would have been very old in order to achieve the dimensions adequate for a coffin.

According to the History of the Yuan Dynasty (Yuan 1947), it was customary for aristocratic Mongols to be returned to their homeland for burial-which today is the territory of Mongolia. The diversity in the origin of artifacts may help us to understand the cultural dimensions of the nobility of the Mongol Empire.

\section{ACKNOWLEDGMENTS}

Archaeological fieldwork was supported by the Asia Research Center at the National University of Mongolia and by the Korean Foundation for Advanced Studies, South Korea. The AMS ${ }^{14} \mathrm{C}$ dating 
and the related research were supported by the Korean Science and Engineering Foundation (M20505050002-05A0905-00210).

\section{REFERENCES}

Amar A. 1934. Mongolyn Tovch Tuuh [A Brief History of Mongolia]. Volume 1. Ulaanbaatar: Ulsyn Khvllin Gazar. In Mongolian.

Anonymous. 2000. Recent archaeological news. China Archaeology and Art Digest. Porcelain and Society 12:192.

Batsaikhan Z. 2002. Khunnu [Xoungnu]. Ulaanbaatar: Mongol Ulsyn Ikh Surguul. In Mongolian.

Bayar D. 2000. Altan Urgiin Yazguurtnii Negen Bulshiig Sudalsan $\mathrm{Ni}$ [Investigations of a Golden Horde Lineage Nobility Tomb]. Ulaanbaatar: Uranbishrlt Khvllin Gazar. In Mongolian.

Bronk Ramsey C. 1995. Radiocarbon calibration and analysis of stratigraphy: the OxCal program. Radiocarbon 37(2):425-30.

Bronk Ramsey C. 2001. Development of the radiocarbon program. Radiocarbon 43(2A):355-63.

Cheoun MK, Kang J, Song YM, Kim JC, Kim IC, Park JH, Youn M. 2001. Pretreatment of iron artifacts and bone at SNU-AMS. Journal of the Korean Physical Society 39:796-8.

Damdinsuren T. 1947. Mongol-un Nigucha Tobchiyan [Secret History of the Mongols]. Ulaanbaatar: Ulusun Keblekü Uiledburi. In Mongolian.

Kim HK. 2005. Comprehensive examinations and interpretations of the relics of the Age of Chingis Khan. In: Ahn BS, Lee DJ, editors. Relics Excavation State and Meaning by the Genghis Khan Age. Seoul: Korean Studies Institute of Korea University. p 83-104. In Korean.

Kim JC, Lee CH, Kim IC, Park JH, Kang J, Cheoun MK, Kim YD, Moon CB. 2000. A new AMS facility in Korea. Nuclear Instruments and Methods in Physics Research B 172(1-4):13-7.

Kim JC, Park JH, Kim IC, Lee C, Cheoun MK, Kang J,
Song YM, Jeong SC. 2001. Progress and protocol at the Seoul National University AMS facility. Journal of the Korean Physical Society 39:778-82.

Lee C, Kim JC, Park JH, Kim IC, Kang J, Cheoun MK, Choi SY, Kim YD, Moon C-B. 2000. Progress in sample preparation system for the Seoul National University AMS facility. Nuclear Instruments and Methods in Physics Research B 172(1-4):454-7.

Park JH. 2003. ${ }^{14} \mathrm{C}$ levels at Mount Chiak and Mount Kyeryong, and the Suess effect in the region of Kyungbokkung [unpublished $\mathrm{PhD}$ dissertation]. Seoul: Seoul National University.

Reimer PJ, Baillie MGL, Bard E, Bayliss A, Beck JW, Bertrand CJH, Blackwell PG, Buck CE, Burr GS, Cutler $\mathrm{KB}$, Damon PE, Edwards RL, Fairbanks RG, Friedrich M, Guilderson TP, Hogg AG, Hughen KA, Kromer B, McCormac G, Manning S, Bronk Ramsey C, Reimer RW, Remmele S, Southon JR, Stuiver M, Talamo S, Taylor FW, van der Plicht J, Weyhenmeyer CE. 2004. IntCal04 terrestrial radiocarbon age calibration, 0-26 cal kyr BP. Radiocarbon 46(3):1029-58.

Rozanski K, Stichler W, Gonfiantini R, Scott EM, Beukens RP, Kromer B, van der Plicht J. 1992. The IAEA ${ }^{14} \mathrm{C}$ intercomparison exercise 1990. Radiocarbon 34(3):506-19.

Tumen D. 2004. Paleoanthropology of eastern Mongolia. Mongolian Journal of Anthropology, Archaeology and Ethnology 1:85-110. In Mongolian.

Turbat T, Amartuvshin C, Erdenebat U. 2003. Egiin Golyn Sav Nutag Dakh Arkheologiin Dursgaluud [Archaeological Monuments of the Egiin Gol Valley]. Ulaanbaatar: Mongolian Institute of Archaeology.

Yuan CL. 1947. History of the Yuan Dynasty. Ulaganbagatur: Monggol Arad Ulus-un Sinjilekui Uqagan-u Kûriyeleng. In Mongolian. 